\title{
A Case of Inhalation Burn-Induced Extensive Tracheal Inflammatory Crust Removed by Ventilating Bronchoscopy under Tracheostomy and Extracorporeal Membrane Oxygenation
}

\author{
Kyoung Ho Park, Joong Hyun Park, Anna Park, and Young Sam Yoo \\ Department of Otorhinolaryngology-Head and Neck Surgery, Sanggye Paik Hospital, Inje University College of Medicine, Seoul, Korea
}

\begin{abstract}
흡입화상 환자에서 기관 절개 및 체외막 산소화 요법 후 환기형 기관지 내시경을 통해 기관 내 광범위한 염증성 가피를 제거한 1 예
\end{abstract}

박경호 · 박중현 · 박안나 · 유영삼

인제대학교 의과대학 상계백병원 이비인후과학교실

\author{
Received June 15, 2015 \\ Revised July 21, 2015 \\ Accepted July 22, 2015 \\ Address for correspondence \\ Young Sam Yoo, MD \\ Department of Otorhinolaryngology- \\ Head and Neck Surgery, \\ Sanggye Paik Hospital, \\ Inje University College of Medicine, \\ 1342 Dongil-ro, Nowon-gu, \\ Seoul 01757, Korea \\ Tel $+82-2-950-1104$ \\ Fax $+82-2-935-6220$ \\ E-mail entyoo@empal.com
}

Foreign body impaction in airway is life-threatening as it can cause total airway obstruction. Such foreign bodies are removed under bronchoscopy in most patients. In some patients, however, the cardiopulmonary condition becomes unstable to undergo ventilating bronchoscopy under general anesthesia to remove the foreign body. In these conditions, extracorporeal membrane oxygenation (ECMO) can be adopted for cardiopulmonary support to stabilize the patient while removing the foreign body. ECMO supports tissue oxygenation and has been shown to improve survival of patients with adult respiratory distress syndrome. ECMO allows lungs to reserve their functions and decreases further lung injuries. The authors report one case of extensive tracheal inflammatory crust removed by ventilating bronchoscopy under tracheostomy and ECMO. Korean J Otorhinolaryngol-Head Neck Surg 2015;58(12):882-5

Key Words Extracorporeal membrane oxygenation · Inhalation burn · Tracheostomy · Ventilating bronchoscopy.

\section{서 론}

기도 이물 흡인이 발생하면 급성 호흡 부전 및 만성 폐질환 을 유발하거나 사망에 이르기도 한다.) 1897 년, Killian이 처 음으로 식도경을 이용하여 기도 이물을 제거한 이후 기관지 내시경술은 기도 이물 제거 방법의 하나로 자리 잡았다. 응급 기도 확보 및 내시경을 이용한 이물 제거 기술의 발전으로 기 도 이물 흡인으로 인한 사망률은 감소하는 추세이다. ${ }^{2)}$ 대부분 의 기도 이물은 기관지 내시경만으로도 제거가 가능하지만 일 부 환자에서는 시술 도중 활력 징후가 불안정해질 수 있어 기 관지 내시경을 삽입할 수 없는데, 이런 경우 기도 이물 제거를 하기 위해 환자의 심폐 기능 안정을 위한 체외막 산소화 요법
을 통해 일시적이고 인공적인 폐 기능 유지를 고려할 수 있다. ${ }^{3)}$

체외막 산소화 요법은 회복 가능성이 있지만 매우 심한 호 흡부전이나 심부전 환자에서 고식적인 치료 방법이 실패한 경 우, 심폐 기능이 회복될 때까지 수일에서 수주 동안 생명 유지 를 도와주는 체외순환의 일종이다. ${ }^{4)}$ 이 요법은 질환 자체를 치료하는 것은 아니고 환자의 가스교환을 도와주어 기계환기 유발성 폐 손상(ventilator-induced lung injury)을 최소화하고 폐의 환기 기능 회복에 필요한 시간을 벌어 주는 치료법이다.5)

저자들은 흡입화상으로 치료받던 환자에게서 기도에 심한 염증성 가피가 생긴 후 지연성 호흡곤란이 발생하였고, 치료 목적으로 기관 절개 및 체외막 산소화 요법 시행 후, 환기형 기관지 내시경을 통하여 이물 역할을 하던 염증성 가피를 제 
거한 1 예를 문헌 고찰과 함께 보고하고자 한다.

\section{증 례}

36세 여자 환자가 의식 불명 상태로 응급실에 내원하였다. 과거력상 특이 소견은 없었고, 화재가 난 아파트 내부에 쓰러 져 있는 것이 발견되었다. 환자는 입원 후 호흡곤란 증세를 보 여 기관 내 삽관을 시행하였고 기계환기를 시작하였으며, 이후

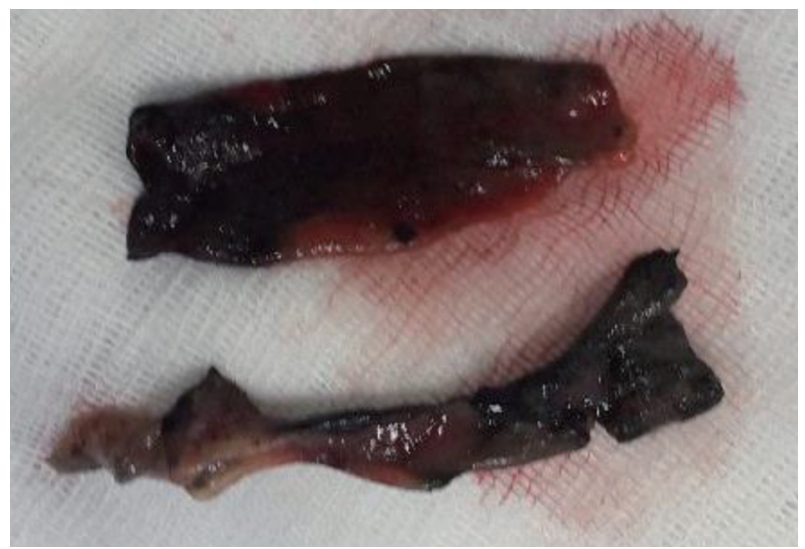

Fig. 1. Removed tracheal inflammatory crust. These crusts were expelled and removed during tracheostomy.

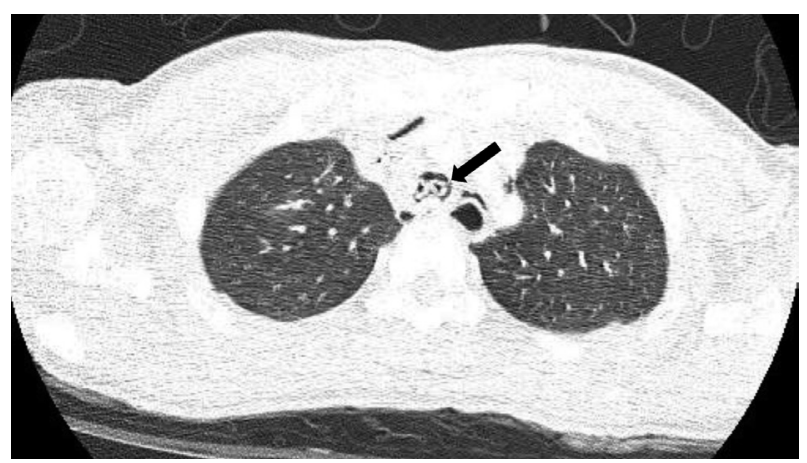

Fig. 2. Crust shadow in trachea. Chest CT showed linear opacity (black arrow) in tracheal lumen.
의식이 회복되었고 호흡곤란 증상도 점차 호전되었다.

6일째 오전 9시경 환자는 갑자기 호흡곤란, 흉통을 호소하 면서 의식이 저하되었고 혈액 내 산소 포화도가 $60 \%$ 까지 떨 어졌다. 기관내관을 통해 ambu-bagging을 하였으나, 청진 시 양측 폐음이 들리지 않았고 혈액 내 산소 포화도는 $30 \%$ 까지 떨어졌다. 수축기 혈압이 $60 \mathrm{~mm} \mathrm{Hg}$ 까지 떨어져 심폐소생술을 시행하였다.

환자는 즉시 이비인후과로 의뢰되었으며 중환자실에서 기 관 절개를 시행하였다. 기관 절개 후 기도 내에 검은색의 물질 이 차 있는 것을 발견하였고 이를 확인하기 위해 기관 절개창 을 통해 굴곡형 기관지경 검사를 하면서 기관 내를 채워서 이 물로 작용하는 탄화된 검은색의 염증성 가피를 제거하였다 (Fig. 1). 환자는 가피 제거 후에도 반복적으로 혈액 내 산소 포 화도가 떨어지는 양상을 보여 경부 및 흉부 전산화단층촬영 을 하였다. 전산화단층촬영상 기도 내강이 박리된 양상을 보 였다(Fig. 2).

기관 절개 후에도 환자의 활력 징후가 안정적으로 유지되지 않아 응급으로 환기형 기관지 내시경을 통한 기관 내 염증성 가피 제거를 계획하였다. 전신 마취 상태에서 환기형 기관지 내시경을 통한 시술의 편리 및 시술 중 저산소증 방지를 위해 흥부외과에서 먼저 정맥-정맥(veno-venous) 체외막 산소화 요법(extracorporeal membrane oxygenation, ECMO)을 시술 하였고, 기관 절개창을 통해 환기형 기관지 내시경을 삽입하 였다. 기도 내의 점막은 물집이 잡혀 있었고 심하게 부어 있었 으며 탄화된 상태였고 기관 내 이물로 작용한 염증성 가피를 성공적으로 제거하였다. 이 가피는 기관 내 점막에 염증이 생 겨 박리된 점막과 점액 등이 엉켜서 생긴 것으로 보였고 길쭉 하게 제거되어 기관 내경을 본뜬 모양으로 딸려 나왔다(Fig. 3). 체외막 산소화 요법은 수술 후 중단하였으며 기계환기로 전 환 후 활력 징후가 정상 범위로 유지되어 시술을 종료하였다.

환자는 기관 절개를 유지한 상태로 2주간 항생제 및 스테로

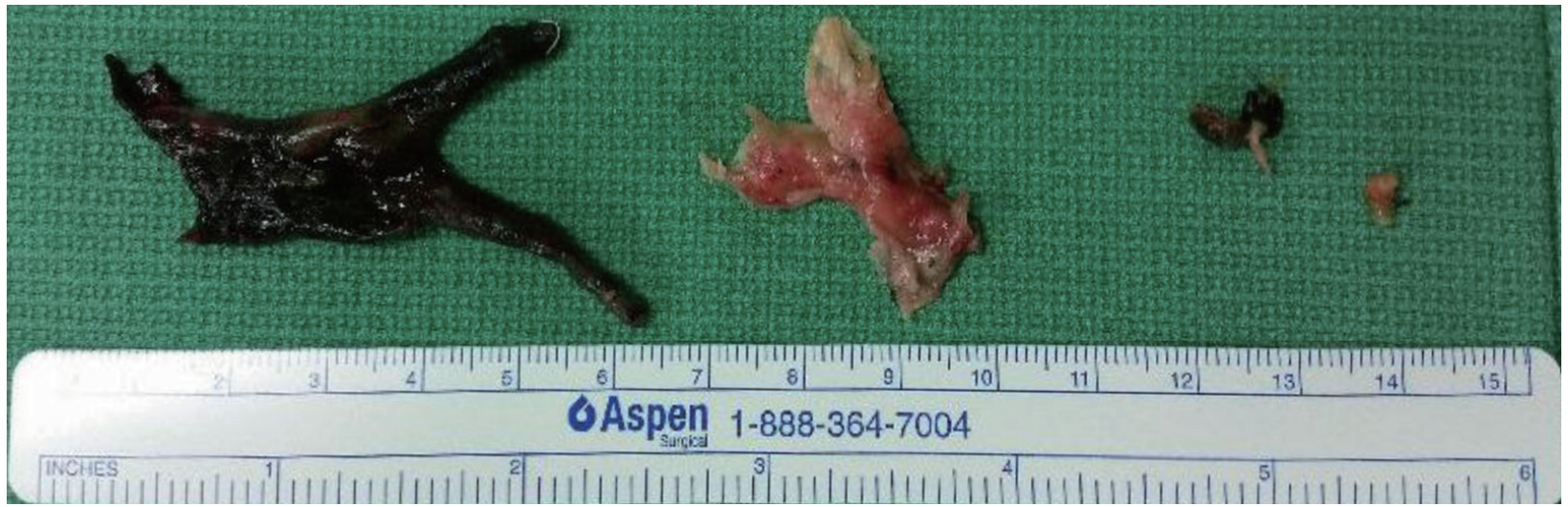

Fig. 3. Removed inflammatory tracheal crust. They were removed via ventilating bronchoscopy under tracheostomy and extracorporeal membrane oxygenation. 


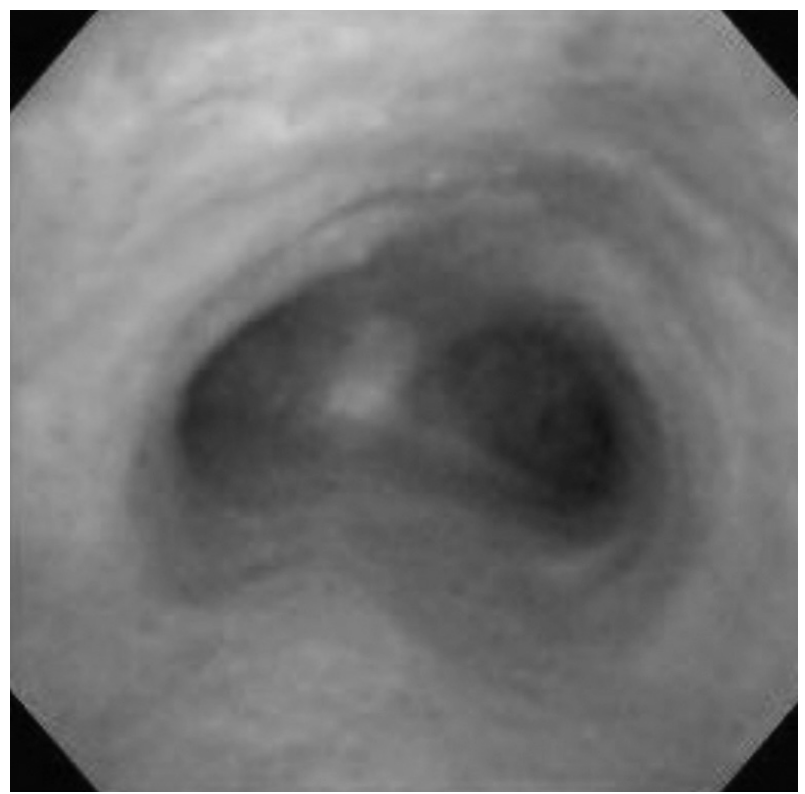

Fig. 4. Bronchoscopic image showed normal airway with some hyperemic mucosa.

이드 정주를 받은 후 호전되어 발관 뒤 퇴원하였다. 시술 직후 및 퇴원 전 촬영한 흥부 방사선 단순촬영 결과, 폐렴, 무기폐, 기흥 등의 합병증 소견은 관찰되지 않았다. 퇴원 1 주 후 외래 방문 시 호흡곤란 및 천명 등의 증상은 없었고 기관 절개 부 위도 흥터 없이 회복되었다. 호흡기 내과에서 퇴원 4주 후 시 행한 연성 기관지 내시경상 기관 점막은 다소 충혈되어 있으 나 손상 및 염증 정도는 호전된 것을 확인할 수 있었다(Fig. 4).

\section{고 찰}

기도의 이물 제거가 늦어지는 경우 합병증과 사망률이 증 가하게 된다. 이를 방지하기 위해서는 빠른 진단과 신속한 이 물 제거가 중요하다. 이물 흡인의 임상 양상 및 치료 방법은 이물의 특성, 흡입 후 진단까지 소요된 시간, 이물의 매복 위 치, 기도 내강의 폐색 정도에 영향을 받는다. ${ }^{6}$

기관지 내 이물의 제거에 있어 환기형 기관지 내시경술을 시행하는 시기는 환자의 상태에 따라 다르며 모든 환자가 다 응급 상황은 아니다. 하지만 본 증례처럼 호흡곤란이 있는 경 우에는 지체 없이 이물 제거를 시행해야 하며, 이물의 흡인 사 실이 비교적 조기에 발견되고 호흡곤란 등의 증상이 없는 경 우에는 6 시간 이상의 금식 시간이 경과한 후 시행하는 것이 안전하다. 환기형 기관지 내시경술을 통한 이물 제거는 가능 하면 30분 이내의 짧은 시간 안에 끝내야 수술 후 성문하 부 종, 기관지 부종 같은 합병증의 발생을 줄일 수 있다. 또한 이 물이 제거된 후 기관지염, 폐렴 등의 문제가 지속될 수 있으므 로 이에 대한 관찰 및 보존적 치료가 필요하다.7)
기도 이물 제거 시 내시경적 접근 이외에 기관 절개술, 개흥 술, 폐 절제술과 같은 관혈적 수술법이 필요한 경우가 있으며, 기관 절개술의 필요성은 $0.3 \sim 4 \%$ 까지 다양하게 보고되고 있 다. ${ }^{8)}$ 본 증례처럼 이물이 너무 크고 기관지 전장에 걸쳐 발생 하여 급성 기도 폐색을 야기시킬 가능성이 높으며 성대나 성 문에 영구적으로 손상을 줄 수 있거나 이물의 특성상 조각조 각으로 제거(piecemeal removal)하면 위험한 경우 기관 절개 술을 고려해 볼 수 있다.9) 또한 거대 기도 이물 제거 및 전 기도 폐색 시 체외막 산소화 요법(ECMO)을 이용하는 경우가 있는 데, 본 증례에서도 같은 이유로 기관 절개와 체외막 산소화 요 법을 동시에 시행하였다. ${ }^{3}$

체외막 산소화 요법은 혈액을 대퇴정맥이나 우심방에 도관 삽입을 통해 배액된 혈액을 산화시키고 이산화탄소를 제거한 후 대퇴동맥이나 상행대동맥을 통해 체내에 다시 공급하는 장치로, 심폐부전이 발생하였을 때 일시적으로 심장 기능 및 폐 기능을 대체하는 수단이다. 이는 기존의 인공호흡기만으로 충분한 체내 산소 및 이산화탄소의 교환이 이루어지지 못하 여 활력 징후 유지가 어려운 환자들에게 적응이 된다. 질환 자 체를 치료하는 것은 아니지만 임상 호전에 필요한 시간 동안 가스교환을 도와주어 추가적인 기계환기 유발성 폐 손상 (ventilator-induced lung injury)을 최소화하면서 회복에 필 요한 시간을 확보할 수 있다. ${ }^{5}$

체외막 산소화 요법은 처음 도입되고 나서 성인성 호흡곤란 증후군(adult respiratory distress syndrome), 신생아 태변 흡 인 증후군, 신생아의 지속적 폐 고혈압, 선천성 횡격막 탈줄증 의 치료 등에서 좋은 성적을 거두었고, 최근에는 전향적, 무작 위 연구인 conventional ventilation or extracorporeal membrane oxygenation for severe adult respiratory failure trial 에 근거하여 급성 호흡 부전이나 심각한 심부전 및 쇼크 환자 등 응급 상황에서 많이 이용되고 있다. ${ }^{4.10)}$ 또한 상기도 수술, 폐 색전증, 약물 남용, 이물 등에 의한 기도 폐색 같은 경우에도 사 용되고 있다. ${ }^{3)}$

본 증례에서는 기관 절개술 후에도 환자의 활력 징후가 유 지되지 않았고 시술 중 기도 폐색의 우려가 있었기 때문에 시 술 전 정맥-정맥 체외막 산소화 요법을 적용하였다. 이 방법으 로 시술 전 적절한 활력 징후 유지, 환기형 기관지 내시경 시술 시 안정된 환경 유지, 그리고 수술 후 폐가 쉴 수 있는 시간의 확보 등을 체외막 산소화 요법을 통해 기대할 수 있었다. ${ }^{11)}$

결론적으로 이물에 의해 급성 기도 폐색이 유발될 가능성이 높거나 기도 확보 및 내과적인 처치 후에도 불안정한 활력 징 후를 보이는 경우, 환기 부전으로 수술 중 심정지 등의 부작용이 우려되는 경우에는 기관 절개술 및 체외막 산소화 요법 후 환 기형 기관지 내시경을 통한 이물 제거를 고려해 볼 수 있겠다. 


\section{REFERENCES}

1) Lim JH, Lee SY, Ryu YJ, Hah JH. A case of tracheal foreign body removed by endoscopic approach with tracheotomy. Korean J Otorhinolaryngol-Head Neck Surg 2014;57(10):723-6.

2) Tan HK, Brown K, McGill T, Kenna MA, Lund DP, Healy GB. Airway foreign bodies (FB): a 10-year review. Int J Pediatr Otorhinolaryngol 2000;56(2):91-9.

3) Ignacio RC Jr, Falcone RA Jr, Brown RL. A case report of severe tracheal obstruction requiring extracorporeal membrane oxygenation. J Pediatr Surg 2006;41(10):E1-4.

4) Kim GW, Choi EY, Hong SB. The treatment of adult respiratory distress syndrome (ARDS) using extracorporeal membrane oxygenation (ECMO). Tuberc Respir Dis (Seoul) 2012;72(1):1-7.

5) Kim T, Cho MJ, Park JJ, Kim DY, Kim SC, Kim IK. Extracorporeal membrane oxygenation in neonates with congenital diaphragmatic hernia: a preliminary experience. J Korean Assoc Pediatr Surg 2011; 17(2):133-8.

6) Koempel JA, Holinger LD. Foreign bodies of the upper aerodigestive tract. Indian J Pediatr 1997;64(6):763-9.

7) Kim BG, Kang JW, Kim YJ, Nam SY. Diagnosis and treatment of bronchial foreign body by ventilating bronchoscopy. Korean $\mathrm{J}$ Bronchoesophagology 2002;8(2):36-42.

8) Zhijun C, Fugao Z, Niankai Z, Jingjing C. Therapeutic experience from 1428 patients with pediatric tracheobronchial foreign body. J Pediatr Surg 2008;43(4):718-21.

9) Marks SC, Marsh BR, Dudgeon DL. Indications for open surgical removal of airway foreign bodies. Ann Otol Rhinol Laryngol 1993; 102(9):690-4.

10) Jeon DG, Kim SK, Kang BJ, Kim HS, Seo PW. Use of ECMO (extracorporeal membrane oxygenation) in cardiac arrest during spinal anesthesia-a case report. Korean J Anesthesiol 2007;53(6): 785-90.

11) Brown KL, Shefler A, Cohen G, DeMunter C, Pigott N, Goldman AP. Near-fatal grape aspiration with complicating acute lung injury successfully treated with extracorporeal membrane oxygenation. Pediatr Crit Care Med 2003;4(2):243-5. 